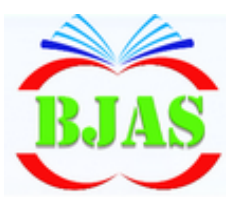

Available online at: http//bjas.bajas.edu.iq

College of Agriculture, University of Basrah

DOi:10.21276/basjas

ISSN $1814-5868$

Basrah J. Agric. Sci., 32(Spec Issue): 47-58, 2019

\section{Basrah \\ Journal of \\ Agricultural \\ Sciences}

E-ISSN: 2520-0860

\title{
Effect of some Agricultural Treatments on Chemical and Qualitative Characters of Five Cucumber hybrids Grown under Unheated Greenhouse
}

\author{
Walled B.M. Allela* \& Shamil Y.H. Al-Hamdani \\ Department of Horticulture and Landscape Design, Faculty of Agriculture and Forestry, \\ University of Mosul, Iraq \\ *Corresponding author e-mail: waleedallela@gmail.com
}

Received 6 April 2019; Accepted 1 June 2019; Available online 4 September 2019

\begin{abstract}
The experiment was implemented in greenhouse at College of Agriculture and Forestry, University of Mosul, During the spring growing season of 2014 to study the evaluation of genetic behavior of some traits in five cucumber hybrids (Raiane, Karol, Sayff, Karima and Baraka) under the effect of fertilization with two plant extracts treatments (control and fertilization with humic acid at concentrate $6 \mathrm{gm}^{-1}$ ) and harvesting fruits in two periods in each (two days or three days) on growth and yield of cucumber. The experiment results subjected to statistical analysis arranged in R.C.B.D. with three replications. The results can be summarized as follows, Leaves content of nutrient elements, The Baraka hybrid exhibited non-significant in $\mathrm{N} \%$ of leaves superiority, and the hybrid Raiane in $\mathrm{P} \%$ of leaves and the hybrid Karima in $\mathrm{K} \%$ of leaves as compared with other hybrids. Plants fertilized with humic acid were surpassed significantly over the non-fertilized plants in $\mathrm{N} \%$ of leaves only, The results revealed non-significance in nutrient elements percentages between the fertilized and nonfertilized plants. Treatments of triple interactions showed a significant increase in traits of $\mathrm{N} \%$ and $\mathrm{P} \%$ of leaves. Yield qualitative trait, The differences did not reached a significant effect between the fertilized and non-fertilized plants, The plants harvested in each of two and three days revealed non-significant differences in all traits except in trait GA3 of leaves, where the plants of two-days harvesting were superior significantly on the plants of three days harvesting
\end{abstract}

Keywords: Fish population, Biodiversity, Euphrates, Ecology, Aquatic environment.

\section{Introduction}

Cucumber (Cucumis sativus L.) is one of the most important summer Cucurbitaceae in the world, including Iraq, and it is important to use it as food for human consumption as it consumes fresh fruit, as well as in the pickling industry (Lower \& Edwards, 1986) Although water accounts for a large percentage of the weight of the fruit, it is characterized by its nutritional and medicinal value of its constituents of $\mathrm{Ca}, \mathrm{P}, \mathrm{K}$, vitamin $\mathrm{C}, \mathrm{B} 1, \mathrm{~B} 2$ and Niacin, as well as protein (Arnaout, 1980). It also helps to heal the wounds and 
complete growth of the body and brain (Robinson \& Decker Walter, 1999). It is a vegetable crop that has been known since ancient times. It was originally cultivated in India for three thousand years ago from India, it moved to China and then to Morocco. It was used extensively by the Greeks and Romans. There is another belief that the original habitat is Central Africa (Whitaker \& Davis, 1962).

Iraq's crop production under protected agriculture conditions for 2012 was 107745 tonnes and planted area 11647 hectares with an average productivity of $9248 \mathrm{~kg}$. 1 hectare (Central Bureau of Statistics Organization, 2013)

The increase in the world's population has led to an increase in demand for food. The focus has been on increasing the production of food crops, regardless of quality. This has led to an increase in the use of chemical additives (fertilizers and pesticides). On the highest output per unit area (Stopes et al., 1996).

It is noted that the method of service cucumber plants under the conditions of protected agriculture is the abundance of chemical fertilizers added through the soil or spray on plants, and most of them are contaminants on toxic that leave a negative impact in the long term on humans and environment in general, so a recent trend in the agricultural specialists (Elia et al., 1998). In recent years, the trend towards the use of organic fertilizers in vegetable fields has increased as a substitute for "chemical fertilizers. The organic fertilizer of humic acid is one of the compounds of humic matter resulting from the decomposition of organic matter (Alnaimi, 1999) for the role of humic acid in improving plant growth by improving the soil structure and increasing the efficiency of roots to absorb water and soluble food in the soil to the plant. To retain water and nutrients, as well as to play an important role in stimulating microbial activity in soil (Phelpstek, 2002).

Recent which have not been sufficiently studied, especially in the production of vegetables for the cucurbitaceous, have focused on the number of days to leave the fruit on the plant. In most of the cucurbitaceous crops, this phenomenon is prevented or inhibited by the formation of new flowers because of their depletion of food due to the phenomenon of inhibition; McCollam (1934), Denna (1973), Cantliffe (1974) and Wien (1997) suggested that leaving the fruits of the cucumber without reaping inhibits the growth and formation of new female flowers and that the ongoing harvesting process eliminates the effect of this phenomenon.

The main objectives of this study can be summarized as follows:

1-Minimize the damage caused by chemical fertilizers and replace them with organic fertilizers (humic acid).

2-To choose the optimal period to harvest the crop (every two days or every three days) inside the green house.

\section{Materials \& Methods}

The study was conducted during the two spring planting seasons of 2014 in one of the $500 \mathrm{~m}^{2}$ heated houses $\left(10 \times 50 \mathrm{~m}^{2}\right)$ at the field of Department of Horticulture and Landscape design Faculty of Agriculture and Forestry, University of Mosul to study and evaluate five different hybrids Karol, Sayff, Karima and Baraka. The five hybrid seeds were on 2/2/2014 in an agricultural medium consisting of house moss and produced by the German company Solinova in agricultural trays 
containing 72 holes for planting seeds in the greenhouse after germination of seeds The arrival of seedlings to the stage of the second was planted in the permanent place inside the greenhouse on 3/3/2014, where the process of transplantation on a length of $2 \mathrm{~m}$ and width of $1 \mathrm{~m}$ and $40 \mathrm{~cm}$ between the plant and another and a distance of $75 \mathrm{~cm}$ between the surface and the other and in the upper third and on the sides of the table according to the design of the complete block design at three replicates, With 10 terraces for each replication 5 hybrid and 2 terraces for each hybrid of the first line of the first treatment (Plant fertilization with humic acid at a concentration of $6 \mathrm{~g} . \mathrm{l}^{-1}+$ harvest per-2 days). And the second terraces for the second treatment (Plant fertilization with humic acid at a concentration of $6 \mathrm{~g} . \mathrm{l}^{-1}+$ harvest per-3 days). The process of adding the humic acid 6 g. $1^{-1}$ by watering the plants from the appearance of the first flower, repeated the spraying every two weeks during the period of the experiment, and was planted the distance left at the beginning and end of the greenhouse seedlings of five plants guarded with a distance of $1 \mathrm{~m}$ between each replicate and another $50 \mathrm{~cm}$ between the experimental duplicate and the other, the number of plants in the experimental duplicate was 10 plants (Five plants in each aspect of the terrace) with the use of beltanol fungicide with irrigation water to protect the seedlings from the disease of damping-off at a concentration of $1 \mathrm{ml}^{-1}$. and periodically weekly as a preventive measure for the disease of seedlings fading. Compound fertilizer 18.18 (NP) was added to the soil prior to transplantation and for all treatments at $50 \mathrm{~kg}$ dunum ${ }^{-1}$ and nitrogen fertilizer $46 \% \mathrm{~N} \%$ at and two weeks between batch (Matloob, et al., 1989). Agricultural services were carried out as is the case in greenhouses for cucumber production from the beginning of the crop and to the last stage of fruit harvesting, such as control of diseases, insects, irrigation and pruning. The leaves and side plants were removed from the beginning of the stem to $50 \mathrm{~cm}$ above the surface of the soil. Training is carried out on one stem and the plant is flattened around the thread as it grows (Abdol \& Mohammed, 1986). The harvest began on 8/4/2014 and ended on $4 / 6 / 2014$, for the date of harvest every two days, but at the time of harvest every three days, it began on 8/4/2014 and ended on 5/6/2014. Nitrogen, phosphorus and potassium were studied in leaves, Gibberellin content in leaves (nano g.g dry weight ${ }^{-1}, \%$ carbohydrate in leaves and fruits, The Duncan (1955) multi-range test was used to compare the averages and the 5\% probability level.

\section{Results \& Discussion}

\section{1-\% Of Nitrogen in leaves:}

The results of table (1) indicated that the highest percentage of the nitrogen element in the leaves was recorded in the hybrid Baraka (1.105\%) which differed significantly from the Raiane hybrid, which gave the lowest percentage $(0.818 \%)$. In the leaves $(1.042 \%)$ compare with non-fertilized plants $(0.934 \%)$, while the differences did not reach the significant limit between the plants fed every two days and every three days in $\%$ of nitrogen in the leaves. The results of the binary interactions between the hybrid and the fertilization treatment indicate that the highest percentage of nitrogen in the leaves was recorded in the hybridized pond (1.239\%) except for the non-fertilized Raiane hybrid, which showed the lowest percentage of nitrogen in leaves $(0.751 \%)$ compared to other hybrids. Between hybrid and harvest, the highest percentage was the Baraka, which was harvested every three days and significantly to the rest of the other 
Allela \& Al-Hamdani/ Basrah J. Agric. Sci., 32 (Special Issue): 47-58, 2019

interactions $(1.141 \%)$, while the hybrid Ryan, which was harvested every three days, the lowest percentage of nitrogen $(0.726 \%)$ is significantly different from other interactions except for the hybrid $(0.910 \%)$ and the karol hybrid, which was harvested every three days $(0.865 \%)$.

Table (1): Effect of hybrid , fertilizer treatment, harvest period and interaction on \% Nitrogen in leaves.

\begin{tabular}{|c|c|c|c|c|c|}
\hline \multirow{2}{*}{ Hybrids } & \multirow{2}{*}{ Fertilizer } & \multicolumn{2}{|c|}{ Harvest period } & \multirow{2}{*}{$\begin{array}{l}\times \text { Hybrids } \\
\text { Fertilizer }\end{array}$} & \multirow{2}{*}{ Mean hybrid } \\
\hline & & 2 Days & 3 Days & & \\
\hline \multirow{2}{*}{ Raiane } & Un Fertilizer & $0.922 \mathrm{bc}$ & $0.579 \mathrm{c}$ & $0.751 \mathrm{c}$ & \multirow{2}{*}{$0.818 \mathrm{~b}$} \\
\hline & Fertilizer & $0.898 \mathrm{~b} \mathrm{c}$ & $0.873 \mathrm{bc}$ & $0.886 \mathrm{~b}-\mathrm{c}$ & \\
\hline \multirow{2}{*}{ Karol } & Un Fertilizer & $1.042 \mathrm{ab}$ & $0.865 \mathrm{bc}$ & $0.953 \mathrm{~b}-\mathrm{c}$ & \multirow{2}{*}{$0.930 \mathrm{ab}$} \\
\hline & Fertilizer & $0.947 \mathrm{abc}$ & $0.865 \mathrm{bc}$ & $0.906 \mathrm{bc}$ & \\
\hline \multirow{2}{*}{ Sayff } & Un Fertilizer & $1.056 \mathrm{ab}$ & $0.944 \mathrm{a}-\mathrm{c}$ & $1.000 \mathrm{abc}$ & \multirow{2}{*}{$022.1 \mathrm{ab}$} \\
\hline & Fertilizer & $0.947 \mathrm{abc}$ & $1.143 \mathrm{a} b$ & $1.045 \mathrm{a} \mathrm{b}$ & \\
\hline \multirow{2}{*}{ Karima } & Un Fertilizer & $0.958 \mathrm{ab}$ & $037.1 \mathrm{ab}$ & $0.997 \mathrm{abc}$ & \multirow{2}{*}{$1.066 \mathrm{a}$} \\
\hline & Fertilizer & $1.045 \mathrm{ab}$ & $1.225 \mathrm{ab}$ & $1.135 \mathrm{ab}$ & \\
\hline \multirow{2}{*}{ Baraka } & Un Fertilizer & $0.963 \mathrm{ab}$ & $0.980 \mathrm{ab}$ & $0.971 \mathrm{bc}$ & \multirow{2}{*}{$1.105 \mathrm{a}$} \\
\hline & Fertilizer & $1.176 \mathrm{ab}$ & $303.1 \mathrm{a}$ & $1.239 \mathrm{a}$ & \\
\hline \multirow{5}{*}{$\begin{array}{c}\text { Hybrids } \\
\qquad \times \\
\text { Period } \\
\text { Harvest }\end{array}$} & Raiane & $0.910 \mathrm{abc}$ & $0.726 \mathrm{c}$ & Mean fertilizer & \\
\hline & Karol & $0.994 \mathrm{ab}$ & $0.865 \mathrm{bc}$ & \multirow[b]{2}{*}{$0.943 \mathrm{~b}$} & \\
\hline & Sayff & $1.001 \mathrm{ab}$ & $034.1 \mathrm{ab}$ & & \\
\hline & Karima & $1.002 \mathrm{ab}$ & $0.131 \mathrm{a}$ & \multirow{2}{*}{$1.042 \mathrm{a}$} & \\
\hline & Baraka & $1.069 \mathrm{ab}$ & $1.141 \mathrm{a}$ & & \\
\hline Fertilizer $\times$ & Un Fertilizer & $0.988 \mathrm{ab}$ & $0.881 \mathrm{~b}$ & & \\
\hline $\begin{array}{l}\text { Period } \\
\text { Harvest }\end{array}$ & Fertilizer & $1.002 \mathrm{ab}$ & $082.1 \mathrm{a}$ & & \\
\hline Har & Mean & $0.955 \mathrm{a}$ & $0.981 \quad \mathrm{a}$ & & \\
\hline
\end{tabular}

*The same letter in each columns mean did not differ significantly at $\mathbf{p}=\mathbf{0 . 0 5}$. 
The differences between them did not reach the significant limit. Dual Interaction between fertilization treatment and harvest periods indicated that the highest percentage of nitrogen in the leaves was obtained in the fertilized and harvested plants every three days at $1.082 \%$, which differed significantly only with non-fertilized plants, which were harvested every three days at a rate of $0.881 \%$. The results of the triple interaction indicate that the hybrid and fertilized baraka every three days gave the highest percentage of nitrogen in the leaves $(1.303 \%)$ compared with the non-fertilized, Every three days, which showed the lowest ratios $(0.579 \%)$ and the other interaction varied between them.

\section{2- \% Phosphorus in leaves}

The results in table (2) indicated that the Raiane hybrid, which recorded the highest phosphorus percentage in leaves $(0.261 \%)$, differed significantly with the Karima hybrid, which gave the lowest percentage of phosphorus in leaves $(0.136 \%)$. The results indicate that the fertilized plants gave the highest percentage of phosphorus $(0.198 \%)$. The differences did not reach the significant limit with the non-fertilized plants, as did the plants that were harvested every two days and every three days, Also the results of dual Interaction between hybrid and fertilization treatment Indicate no significant differences in the ratio of phosphorus in the leaves to all interaction and dual Interaction. For the hybrid with the harvests, the Raiane hybrid harvested every two days showed the highest phosphorus percentage $(0.310 \%)$, significantly higher than the two-days Sayff hybrid $(0.136 \%)$ and the Karima harvest period $(0.143 \%$ and $0.129 \%$ respectively). The differences between the fertilization treatment and the harvests also showed no significant differences between the plants and all the interactions, the triple interaction of the hybrid, the fertilization factors and the harvest periods. The hybrid Sayff, which was harvested every three days $(0.365 \%)$, while the lowest percentage of phosphorus was found in the non-fertilized Karima hybrid, which was harvested every three days $(0.086 \%)$, while the phosphorus ratios differed between them in the other interaction.

\section{3- Potassium in leaves}

The results of table (3) indicated that the Karima hybrid gave the highest potassium content in the leaves $(0.839 \%)$, which was significantly superior to the Sayff hybrid $(0.596 \%)$ which showed the lowest ratios of potassium, while the differences did not reach the significant limit between the Karima and the rest of the hybrid, The results also showed no significant differences between the fertilized and non-fertilized plants, as well as between the plants that were harvested every two days and every three days in the potassium ratios in the leaves, in addition to all the bilateral and trilateral interactions. The differences did not reach the significant differences of $\%$ potassium in leaves.

\section{4- Content of Gibberellin in the leaves (ng- mm dry weight)}

Table (4) showed significant differences in the content of Gibberellin in the leaves of Karima. The hybrid showed the highest values (1068.670), significantly higher than all other hybrids except hybrids sayff (1007.970). The differences between them did not reach the significant. $(906,420)$, but did not exceed the significant with the nonfertilized plants $(898,100)$ for this characteristic, the plants that harvested every 
Allela \& Al-Hamdani/ Basrah J. Agric. Sci., 32 (Special Issue): 47-58, 2019

Table (2): Effect of hybrid, fertilizer treatment, harvest period and interaction on \% phosphorus in leaves.

\begin{tabular}{|c|c|c|c|c|c|}
\hline \multirow{2}{*}{ Hybrids } & \multirow{2}{*}{ Fertilizer } & \multicolumn{2}{|c|}{ Harvest period } & \multirow{2}{*}{$\begin{array}{l}\times \text { Hybrids } \\
\text { Fertilizer }\end{array}$} & \multirow{2}{*}{ Mean hybrid } \\
\hline & & 2 Days & 3 Days & & \\
\hline \multirow{2}{*}{ Raiane } & Un Fertilizer & $0.310 \mathrm{ab}$ & $0.213 \mathrm{a}-\mathrm{c}$ & $0.262 \mathrm{a}$ & \multirow{2}{*}{$0.261 \mathrm{a}$} \\
\hline & Fertilizer & $0.310 \mathrm{ab}$ & $0.212 \mathrm{a}-\mathrm{c}$ & $0.261 \mathrm{a}$ & \\
\hline \multirow{2}{*}{ Karol } & Un Fertilizer & $0.210 \mathrm{abc}$ & $0.170 \mathrm{a}-\mathrm{c}$ & $0.190 \mathrm{a}$ & \multirow{2}{*}{$0.177 \mathrm{ab}$} \\
\hline & Fertilizer & $0.156 \mathrm{abc}$ & $0.172 \mathrm{a}-\mathrm{c}$ & $0.164 \mathrm{a}$ & \\
\hline \multirow{2}{*}{ Sayff } & Un Fertilizer & $0.130 \mathrm{bc}$ & $0.101 \mathrm{bc}$ & $0.115 \mathrm{a}$ & \multirow{2}{*}{$184.0 \mathrm{ab}$} \\
\hline & Fertilizer & $0.142 \mathrm{bc}$ & $0.365 \mathrm{a}$ & $0.253 \mathrm{a}$ & \\
\hline \multirow{2}{*}{ Karima } & Un Fertilizer & $0.144 \mathrm{bc}$ & $0.086 \mathrm{c}$ & $0.115 \mathrm{a}$ & \multirow{2}{*}{$0.136 \mathrm{~b}$} \\
\hline & Fertilizer & $0.141 \mathrm{bc}$ & $0.173 \mathrm{abc}$ & $0.157 \mathrm{a}$ & \\
\hline \multirow{2}{*}{ Baraka } & Un Fertilizer & $0.178 \mathrm{abc}$ & $0.211 \mathrm{abc}$ & $0.194 \mathrm{a}$ & \multirow{2}{*}{$0.174 \mathrm{ab}$} \\
\hline & Fertilizer & $0.154 \mathrm{abc}$ & $0.156 \mathrm{abc}$ & $0.155 \mathrm{a}$ & \\
\hline \multirow{5}{*}{$\begin{array}{c}\text { Hybrids } \\
\qquad \times \\
\text { Period } \\
\text { Harvest }\end{array}$} & Raiane & $0.310 \mathrm{a}$ & $0.213 \mathrm{ab}$ & Mean fertilizer & \\
\hline & Karol & $0.183 \mathrm{ab}$ & $0.171 \mathrm{ab}$ & \multirow{2}{*}{$0.175 \mathrm{a}$} & \\
\hline & Sayff & $0.136 \mathrm{~b}$ & $0.233 \mathrm{ab}$ & & \\
\hline & Karima & $0.143 \mathrm{~b}$ & $0.129 \mathrm{~b}$ & \multirow{2}{*}{$0.198 \mathrm{a}$} & \\
\hline & Baraka & $0.166 \mathrm{ab}$ & $0.183 \mathrm{a} b$ & & \\
\hline Fertilizer $\times$ & Un Fertilizer & $0.194 \mathrm{a}$ & $0.156 \mathrm{a}$ & & \\
\hline $\begin{array}{c}\text { Period } \\
\text { Harvest }\end{array}$ & Fertilizer & $0.180 \mathrm{a}$ & $0.215 \mathrm{a}$ & & \\
\hline \multicolumn{2}{|c|}{ Harvest Mean } & $0.187 \mathrm{a}$ & $0.186 \mathrm{a}$ & & \\
\hline
\end{tabular}

*The same letter in each columns mean did not differ significantly at $\mathbf{p}=0.05$.

every three days $(809.370 \%)$. The results of the bilateral interaction between the hybrid and the fertilization treatment indicated that the highest Gibberellin content in the leaves was recorded in the non-fertilized Karima hybrid (1101.920), unlike the non-fertilized Baraka, which gave the lowest percentages (728.260). two days showed a significant superiority in their content (995.150) compared to plants In the bilateral interaction 
between the hybrid and the harvest period, the Sayff hybrid and the harvested showed every two days the highest (1257.970), significantly superior to all other bilateral interactions

Table (3): Effect of hybrid, fertilizer treatment, harvest period and interaction on potassium in leaves.

\begin{tabular}{|c|c|c|c|c|c|}
\hline \multirow{2}{*}{ Hybrids } & \multirow{2}{*}{ Fertilizer } & \multicolumn{2}{|c|}{ Harvest period } & \multirow{2}{*}{$\begin{array}{l}\text { Hybrids } \\
\qquad \times \\
\text { Fertilizer }\end{array}$} & \multirow{2}{*}{ Mean hybric } \\
\hline & & 2 Days & 3 Days & & \\
\hline \multirow{2}{*}{ Raiane } & Un Fertilizer & $0.568 \mathrm{a}$ & $0.587 \mathrm{a}$ & $0.577 \mathrm{a}$ & \multirow{2}{*}{$0.676 \mathrm{ab}$} \\
\hline & Fertilizer & $0.824 \mathrm{a}$ & $0.726 \mathrm{a}$ & $0.775 \mathrm{a}$ & \\
\hline \multirow{2}{*}{ Karol } & Un Fertilizer & $0.583 \mathrm{a}$ & $0.837 \mathrm{a}$ & $0.710 \mathrm{a}$ & \multirow{2}{*}{$0.732 \mathrm{ab}$} \\
\hline & Fertilizer & $0.745 \mathrm{a}$ & $0.762 \mathrm{a}$ & $0.754 \mathrm{a}$ & \\
\hline \multirow{2}{*}{ Sayff } & Un Fertilizer & $0.612 \mathrm{a}$ & $0.529 \mathrm{a}$ & $0.570 \mathrm{a}$ & \multirow{2}{*}{$0.596 \mathrm{~b}$} \\
\hline & Fertilizer & $0.633 \mathrm{a}$ & $0.612 \mathrm{a}$ & $0.622 \mathrm{a}$ & \\
\hline \multirow{2}{*}{ Karima } & Un Fertilizer & $0.862 \mathrm{a}$ & $0.766 \mathrm{a}$ & $0.814 \mathrm{a}$ & \multirow{2}{*}{$0.839 \mathrm{a}$} \\
\hline & Fertilizer & $0.891 \mathrm{a}$ & $0.837 \mathrm{a}$ & $0.864 \mathrm{a}$ & \\
\hline \multirow{2}{*}{ Baraka } & Un Fertilizer & $0.658 \mathrm{a}$ & $0.629 \mathrm{a}$ & $0.643 \mathrm{a}$ & \multirow{2}{*}{$0.705 \mathrm{ab}$} \\
\hline & Fertilizer & $0.662 \mathrm{a}$ & $0.870 \mathrm{a}$ & $0.766 \mathrm{a}$ & \\
\hline \multirow{5}{*}{$\begin{array}{c}\text { Hybrids } \\
\times \\
\text { Period Harvest }\end{array}$} & Raiane & $0.696 \mathrm{a}$ & $0.657 \mathrm{a}$ & $\begin{array}{c}\text { Mean } \\
\text { fertilizer }\end{array}$ & \\
\hline & Karol & $0.664 \mathrm{a}$ & $0.799 \mathrm{a}$ & \multirow{2}{*}{$0.663 \mathrm{a}$} & \\
\hline & Sayff & $0.622 \mathrm{a}$ & $0.570 \mathrm{a}$ & & \\
\hline & Karima & $0.876 \mathrm{a}$ & $0.802 \mathrm{a}$ & \multirow{2}{*}{$0.756 \mathrm{a}$} & \\
\hline & Baraka & $0.660 \mathrm{a}$ & $0.749 \mathrm{a}$ & & \\
\hline Fertilizer $\times$ & Un Fertilizer & $0.665 \mathrm{a}$ & $0.669 \mathrm{a}$ & & \\
\hline Period Harvest & Fertilizer & $0.751 \mathrm{a}$ & $0.761 \mathrm{a}$ & & \\
\hline \multicolumn{2}{|c|}{ Harvest Mean } & $0.704 \mathrm{a}$ & $0.715 \mathrm{a}$ & & \\
\hline
\end{tabular}

* The same letter in each columns mean did not differ significantly at $\mathbf{p}=\mathbf{0 . 0 5}$. 
except for the hybrid and carnivorous every two days (1129.640). The difference between them did not reach the significant, and the harvested every three days, which showed the lowest ratios (647.800). The results of the bilateral interaction between fertilization and

Table (4): Effect of hybrid, fertilizer treatment, harvest period and interaction on \%GA ${ }_{3}$ in leaves.

\begin{tabular}{|c|c|c|c|c|c|}
\hline \multirow{2}{*}{ Hybrids } & \multirow{2}{*}{ Fertilizer } & \multicolumn{2}{|c|}{ Harvest period } & \multirow{2}{*}{$\begin{array}{c}\text { Hybrids } \\
\text { Fertilizer× }\end{array}$} & \multirow{2}{*}{ Mean hybrid } \\
\hline & & 2 Days & 3 Days & & \\
\hline \multirow{2}{*}{ Raiane } & Un Fertilizer & g- c 873.600 & h 747.200 & bc 810.400 & \multirow{2}{*}{ b 781.340} \\
\hline & Fertilizer & e-b 956.200 & h 548.400 & c752.290 & \\
\hline \multirow{2}{*}{ Karol } & Un Fertilizer & g c 850.600 & h-e 745.500 & bc 798.030 & \multirow{2}{*}{ b 807.610} \\
\hline & Fertilizer & dh 797.800 & g c- 836.600 & bc 817.190 & \\
\hline \multirow{2}{*}{ Sayff } & Un Fertilizer & b a 1201.100 & $f-c \quad 902.600$ & a 1051.890 & \multirow{2}{*}{ a 1007.970} \\
\hline & Fertilizer & a 1314.800 & h- g 613.300 & b a 964.050 & \\
\hline \multirow{2}{*}{ Karima } & Un Fertilizer & a 1296.800 & $\mathrm{f}-\mathrm{c} 907.000$ & a 1101.920 & \multirow{2}{*}{ a 1068.670} \\
\hline & Fertilizer & be 962.500 & $\mathrm{c}-\mathrm{a} 1108.400$ & a 1035.410 & \\
\hline \multirow{2}{*}{ Baraka } & Un Fertilizer & h-d 802.500 & h-f $\quad 654.000$ & c728.260 & \multirow{2}{*}{ b 845.710} \\
\hline & Fertilizer & f c 895.700 & $d-b \quad 1030.600$ & b a 963.150 & \\
\hline \multirow{5}{*}{$\begin{array}{c}\text { Hybrids } \\
\times \\
\text { Period } \\
\text { Harvest }\end{array}$} & Raiane & d-c 914.890 & e647.800 & Mean fertilizer & \\
\hline & Karol & de 824.150 & de 791.070 & \multirow{2}{*}{ a 898.100} & \\
\hline & Sayff & a $\quad 1257.970$ & de 757.970 & & \\
\hline & Karima & b a 1129.640 & bc 1007.690 & \multirow{2}{*}{ a 906.420} & \\
\hline & Baraka & $\mathrm{d}-\mathrm{c} 849.110$ & d-c 842.300 & & \\
\hline \multirow{2}{*}{$\begin{array}{c}\times \text { Fertilizer } \\
\text { Period } \\
\text { Harvest }\end{array}$} & Un Fertilizer & a 1004.930 & b $\quad 791.270$ & & \\
\hline & Fertilizer & a 985.370 & b 827.460 & & \\
\hline Harv & Mean & a 995.150 & b 809.370 & & \\
\hline
\end{tabular}

The same letter in each columns mean did not differ significantly at $\mathbf{p}=\mathbf{0 . 0 5}$.

harvest periods indicated that the highest gibberellin content in the leaves was recorded 
in the non-fertilized and fertilized plants, which were harvested every two days (1004.930 and 985.370 respectively), which showed significant superiority over the non-

fertilized, 791.230 and 827.460), respectively. For triple interaction between hybrids, fertilization treatment and harvest periods.

Table (5): Effect of hybrid, fertilizer treatment, harvest period and interaction on carbohydrates in leaves.

\begin{tabular}{|c|c|c|c|c|c|}
\hline \multirow{2}{*}{ Hybrids } & \multirow{2}{*}{ Fertilizer } & \multicolumn{2}{|c|}{ Harvest period } & \multirow{2}{*}{$\begin{array}{c}\text { Hybrids } \\
\quad \times \\
\text { Fertilizer }\end{array}$} & \multirow{2}{*}{ Mean hybric } \\
\hline & & 2 Days & 3 Days & & \\
\hline \multirow{2}{*}{ Raiane } & Un Fertilizer & $1.839 \mathrm{a}$ & $1.874 \mathrm{a}$ & $1.856 \mathrm{ab}$ & \multirow{2}{*}{$1.861 \mathrm{a}$} \\
\hline & Fertilizer & $1.874 \mathrm{a}$ & $1.857 \mathrm{a}$ & $1.865 \mathrm{ab}$ & \\
\hline \multirow{2}{*}{ Karol } & Un Fertilizer & $1.539 \mathrm{a}$ & $1.656 \mathrm{a}$ & $1.598 \mathrm{~b}$ & \multirow{2}{*}{$1.621 \mathrm{a}$} \\
\hline & Fertilizer & $1.758 \mathrm{a}$ & $1.532 \mathrm{a}$ & $1.645 \mathrm{ab}$ & \\
\hline \multirow{2}{*}{ Sayff } & Un Fertilizer & $1.705 \mathrm{a}$ & $1.680 \mathrm{a}$ & $1.693 \mathrm{ab}$ & \multirow{2}{*}{$1.741 \mathrm{a}$} \\
\hline & Fertilizer & $1.649 \mathrm{a}$ & $1.930 \mathrm{a}$ & $1.790 \mathrm{ab}$ & \\
\hline \multirow{2}{*}{ Karima } & Un Fertilizer & $1.733 \mathrm{a}$ & $1.885 \mathrm{a}$ & $1.809 \mathrm{ab}$ & \multirow{2}{*}{$1.835 \mathrm{a}$} \\
\hline & Fertilizer & $1.876 \mathrm{a}$ & $1.846 \mathrm{a}$ & $1.861 \mathrm{ab}$ & \\
\hline \multirow{2}{*}{ Baraka } & Un Fertilizer & $1.898 \mathrm{a}$ & $1.889 \mathrm{a}$ & $1.893 \mathrm{a}$ & \multirow{2}{*}{$1.900 \mathrm{a}$} \\
\hline & Fertilizer & $1.902 \mathrm{a}$ & $1.913 \mathrm{a}$ & $1.908 \mathrm{a}$ & \\
\hline \multirow{3}{*}{$\begin{array}{c}\text { Hybrids } \\
\times\end{array}$} & Raiane & $1.856 \mathrm{ab}$ & $1.865 \mathrm{a}$ & Mean fertilizer & \\
\hline & Karol & $1.649 \mathrm{ab}$ & $1.594 \mathrm{~b}$ & \multirow{2}{*}{$1.770 \mathrm{a}$} & \\
\hline & Sayff & $1.677 \mathrm{ab}$ & $1.805 \mathrm{ab}$ & & \\
\hline \multirow[t]{2}{*}{ Period Harvest } & Karima & $1.804 \mathrm{ab}$ & $1.865 \mathrm{a}$ & \multirow{2}{*}{$1.814 \mathrm{a}$} & \\
\hline & Baraka & $1.900 \mathrm{a}$ & $1.901 \mathrm{a}$ & & \\
\hline Fertilizer $\times$ & Un Fertilizer & $1.743 \mathrm{a}$ & $1.797 \mathrm{a}$ & & \\
\hline Period Harvest & Fertilizer & $1.812 \mathrm{a}$ & $1.816 \mathrm{a}$ & & \\
\hline \multicolumn{2}{|c|}{ Harvest Mean } & $1.777 \mathrm{a}$ & $1.806 \mathrm{a}$ & & \\
\hline
\end{tabular}

The same letter in each columns mean did not differ significantly at $\mathbf{p}=\mathbf{0 . 0 5}$. 
The two-days hybrid fertilized, which was harvested every two days, recorded the highest Gibberellin content in the leaves (1314.800), significantly higher than all other triple interactions, except for the nonfertilized Sayff, which was harvested every two days (1201.100) and the non-fertilized Karima hybrid, which was harvested every two days (1296.800), and the Karima hybrid, which was harvested every three days (1108.400). The difference between them was not significant.

The lowest content in the leaves was recorded in the Raiane hybrid, which was harvested every three days (548.400).

\section{5-\% Carbohydrates in leaves}

The results of table (5) indicated that $\%$ of carbohydrates in leaves were not significantly affected by different hybrids, As well as different fertilization and harvest periods, As for the bilateral interaction between the hybrid and the fertilization treatment, the hybrid recorded a fertilized and non-fertilized Barak. The highest percentage of carbohydrate in leaves (1.908\% and $1.893 \%$ ), respectively, was significantly higher than the non-fertilized Karol Hybrid, which in turn gave the lowest percentage of carbohydrates in leaves $(1.598 \%)$ In general, the results of the hybrid interactions between the harvest and the harvest period indicate that the hybrid plants Baraka and two harvest periods $(1.900 \%$ and $1.901 \%)$, respectively.

It has given the highest proportions and significantly, superior only to the hybrid Karol plants harvested every three days $(1.594 \%)$, which in turn gave the lowest percentages in this characteristic. In the bilateral interaction between fertilization and harvest periods, the results showed no significant differences between the plants in the percentage of carbohydrates in the leaves. In addition, the results of triple interaction between the hybrid and the fertilization factors and the two harvest periods indicate that the differences in percentage carbohydrate in the leaves did not reach significant between all the plants.

\section{6-\% Carbohydrates in fruits}

The results of table (6) showed that there are no significant differences between the hybrids five. Percentage of carbohydrates in fruits .As well as between fertilization and harvesting, as for bilateral interaction between hybrid and fertilization treatment.

The results indicated that the highest ratios were recorded in the Raiane hybrid $(0.985 \%)$, which was significantly higher than the fertilized Baraka, which gave the lowest percentage $(0.475 \%)$. Differences did not reach the significant between other interactions. The results of the binary interaction between the hybrid and the harvest period showed that the highest percentage of carbohydrates in the fruits was recorded in the Raiane hybrid and the harvest every two days $(1.041 \%)$ superior to the rest of the other interactions, And that the lowest percentage of carbohydrates in fruits recorded in the Baraka hybrid and harvested every three days $(0.486 \%)$.

As for the binary interaction between the fertilization coefficients and the harvest periods, the differences did not reach the significant and all the interactions. The results of triple interactions between hybrid and fertilization and harvest period showed that 
the highest percentage of carbohydrate in fruits was obtained in Raiane fertilized hybrid, which is harvested every two days $(1.153 \%)$, which is only significantly higher The Karima hybrid fertilized And was harvested every three days $(0.373 \%)$ which gave the lowest ratios, and the patented Baraka hybrid, which was harvested every three days $(0.422 \%)$, while the differences did not reach the significant with the rest of the other triple interactions.

Table (6): Effect of hybrid, fertilizer treatment, harvest period and interaction on carbohydrates in fruits.

\begin{tabular}{|c|c|c|c|c|c|}
\hline \multirow{2}{*}{ Hybrids } & \multirow{2}{*}{ Fertilizer } & \multicolumn{2}{|c|}{ Harvest period } & \multirow{2}{*}{$\begin{array}{c}\text { Hybrids } \\
\quad \times \\
\text { Fertilizer }\end{array}$} & \multirow{2}{*}{ Mean hybrid } \\
\hline & & 2 Days & 3 Days & & \\
\hline \multirow{2}{*}{ Raiane } & Un Fertilizer & $0.930 \mathrm{ab}$ & $0.767 \mathrm{ab}$ & $0.848 \mathrm{ab}$ & \multirow{2}{*}{$0.917 \mathrm{a}$} \\
\hline & Fertilizer & $153.1 \mathrm{a}$ & $0.818 \mathrm{ab}$ & $0.985 \mathrm{a}$ & \\
\hline \multirow{2}{*}{ Karol } & Un Fertilizer & $0.825 \mathrm{ab}$ & $0.740 \mathrm{ab}$ & $0.782 \mathrm{ab}$ & \multirow{2}{*}{$0.852 \mathrm{a}$} \\
\hline & Fertilizer & $0.824 \mathrm{ab}$ & $1.021 \mathrm{ab}$ & $0.932 \mathrm{ab}$ & \\
\hline \multirow{2}{*}{ Sayff } & Un Fertilizer & $0.416 \mathrm{~b}$ & $0.792 \mathrm{ab}$ & $0.604 \mathrm{ab}$ & \multirow{2}{*}{$0.616 \mathrm{a}$} \\
\hline & Fertilizer & $0.700 \mathrm{ab}$ & $0.557 \mathrm{ab}$ & $0.628 \mathrm{ab}$ & \\
\hline \multirow{2}{*}{ Karima } & Un Fertilizer & $0.810 \mathrm{ab}$ & $0.898 \mathrm{ab}$ & $0.854 \mathrm{ab}$ & \multirow{2}{*}{$0.705 \mathrm{a}$} \\
\hline & Fertilizer & $0.739 a b$ & $0.373 \mathrm{~b}$ & $0.556 \mathrm{ab}$ & \\
\hline \multirow{2}{*}{ Baraka } & Un Fertilizer & $0.598 \mathrm{ab}$ & $0.551 \mathrm{ab}$ & $0.574 \mathrm{ab}$ & \multirow{2}{*}{$52.0 \mathrm{a}$} \\
\hline & Fertilizer & $0.528 \mathrm{ab}$ & $0.422 \mathrm{~b}$ & $0.475 \mathrm{~b}$ & \\
\hline \multirow{5}{*}{$\begin{array}{c}\text { Hybrids } \\
\times \\
\text { Period Harvest }\end{array}$} & Raiane & $1.041 \mathrm{a}$ & $0.793 \mathrm{ab}$ & $\begin{array}{c}\text { Mean } \\
\text { fertilizer }\end{array}$ & \\
\hline & Karol & $0.824 \mathrm{ab}$ & $0.880 \mathrm{ab}$ & \multirow{2}{*}{$0.732 \mathrm{a}$} & \\
\hline & Sayff & $0.558 \mathrm{~b}$ & $0.674 \mathrm{ab}$ & & \\
\hline & Karima & $0.775 \mathrm{ab}$ & $0.635 \mathrm{ab}$ & \multirow{2}{*}{$0.713 \mathrm{a}$} & \\
\hline & Baraka & $0.563 \mathrm{~b}$ & $0.486 \mathrm{~b}$ & & \\
\hline Fertilizer $\times$ & Un Fertilizer & $0.716 \mathrm{a}$ & $0.749 \mathrm{a}$ & & \\
\hline Period Harvest & Fertilizer & $0.789 \mathrm{a}$ & $0.638 \mathrm{a}$ & & \\
\hline \multicolumn{2}{|c|}{ Harvest Mean } & $0.752 \mathrm{a}$ & $0.694 \mathrm{a}$ & & \\
\hline
\end{tabular}


The same letter in each columns mean did not differ significantly at $\mathbf{p}=\mathbf{0 . 0 5}$.

\section{Conclusion}

1-The Baraka hybrid exhibited nonsignificant in $\mathrm{N} \%$ of leaves superiority, and the hybrid Raiane in $\mathrm{P} \%$ of leaves and the hybrid Karima in $\mathrm{K} \%$ of leaves as comparing with other hybrids.

2-The plants harvested in each of two \& three days revealed non-significant differences in all traits except in trait GA3 of leaves , where the plants of 2 days harvesting were superior significantly on the plants of 3 days harvesting.

\section{Acknowledgement}

With sincere respects and gratitude, we would like to express deep thanks to Dr. Hussain AlBayaty and Mr. Ahmed Abd-Al-Raheem from College of Agriculture and Forestry, University of Mosul, for assistance me in Data analysis of this manuscript.

Conflict of interest: The authors declare that they have no conflict of interest.

\section{References}

Abdol, K.S. \& Mohammed, A.A.K. (1986). The Vegetable Physiology. Univ. Mosul Print: $118 \mathrm{pp}$ (In Arabic).

Alnaeimi, S.N.E.A. (1999). Soil Fertilization and Fertility, Aldar Printing. Min. High. Educ. Univ. Mosul: 210pp. (In Arabic).

Arnaout, M.E. (1980). Herbs and Medicinal plants Food and medicine. Egyptian Lebanese aldar: 78pp. (In Arabic).

Cantliffe , D.J. (1974). Promotion of fruit set and reduction of seed number in pollination of cucumber by chlorflurenel. Hort. Sci., 9: 577-578.
Central Bureau of Statistics Organization (2013). Production of secondary crops and vegetables by governorates. Directorate of Agricultural Statistics, Ministry of Planning: 211pp. (In Arabic).

Denna, D.W. (1973). Effect of genetic partheno carpy and gynoecious flowering habit on fruit production and growth of cucumber (Cucumis sativus L.). J. Am. Soc. Hort. Sci., 98: 602-604.

Duncan, D.B. (1955). Multiple range and Multiple F-tests. Biometrics, 11: 1-4.

Elia, A.; Santamaria, P. \& Serio, F. (1998). Nitrogen nutrition yield and quality of Spinach. J. Sci. Food Agric., 76: 341-346.

Lower, R.L. \& Edwards, M.D. (1986). Breeding vegetable Crops. A.W. Pub. Co. Inc. West Port, Connecticut.: 86pp.

Matloob, A.N.; Ezideen, S.M. \& Mohamad, K.A. (1989). Production Vegetable. First one, Univ. Mosul, Min. High. Educ. Sci. Res. 189pp. (In Arabic).

McCollam, J.P. (1934). Vegetable and reproductive responses associated with fruit development in cucumber. Memoir, No.163. Cornell Univ. Agric. Exp. Stat.: $31 \mathrm{pp}$.

Phelpstek, L.D. (2002). Structure, properties, and soil Applicant. http://www.com/ clints/humic acid.html. Page 30 f 9.

Robinson, R.W. \& Decker-Walter, D.S. (1999). Cucurbits. CAB Int., Univ. Cambridge Press: 49pp.

Stopes, C.; Millington, S. \& Woodward, L. (1996). The development of organic movement. Agric. Ecosys. Environ, 57(2-3): 189-196 
Allela \& Al-Hamdani/ Basrah J. Agric. Sci., 32 (Special Issue): 47-58, 2019

Whitaker, L.K. \& Davis. G.N. (1962). Cucurbits botany cultivation and utilization. Interscience Pub., INC. New York.: 119pp.
Wien, H.C. (1997). The Physiology of Vegetable Crops. CAB Int. Univ. Press Cambridge: 218pp. 